\title{
Evaluation in healthcare organizations: a literature review about innovation assessment
}

\author{
Avaliação em organizações de saúde: uma revisão bibliográfica sobre avaliação de \\ inovações
}
La evaluación en las organizaciones de salud: una revisión de la literatura sobre la evaluación de las innovaciones

\section{Breitner Gomes Chaves ${ }^{1 *}$, Catherine Briand ${ }^{2}$, Khayreddine Bouabida ${ }^{1}$, Carol Giba Bottger Garcia ${ }^{1}$.}

\begin{abstract}
Objective: This article identifies and provides the reader with the basis for evaluating the innovations proposed in healthcare organizations and highlights determinants to consider when implementing them. Bibliographic review: There is no complete, exhaustive, and absolute definition of health evaluation. Several evaluative approaches and tools were identified. They can be adapted and used according to the evaluator's evaluative objectives, paradigms, and theoretical influences. Moreover, essential concepts regarding the implementation of innovations were considered and synthesized, allowing the reader to understand the complexity of this phase and its impact on the success of innovations. Final considerations: Although the evaluative field is broad and has several distinct concepts, this article presents a synthesis of concepts that would support decision-makers in evaluating their organization's innovation process. Furthermore, the present paper enables a better understanding of the risks of success or failure of interventions (or innovation) from a comprehensive perspective of the critical determinants in the implementation phase.
\end{abstract}

Keywords: Health evaluation, Organizational innovation, Health intervention, Implementation.

\section{RESUMO}

Objetivo: Esse artigo identifica e fornece ao leitor as bases para um processo avaliativo das inovações propostas em organizações de saúde, assim como evidenciar determinantes que devem ser considerados no momento de sua implantação. Revisão bibliográfica: Não há uma definição de avaliação em saúde que seja completa, exaustiva e absoluta. Diversas abordagens e ferramentas avaliativas foram identificadas, podendo ser adaptadas e usadas em função dos objetivos avaliativos, paradigmas e influências teóricas do avaliador. Além disso, considerações relevantes sobre o processo de implantação das inovações foram evidenciadas e sintetizadas permitindo ao leitor entender melhor a complexidade dessa fase e seu impacto no sucesso das inovações propostas. Considerações finais: Embora o campo avaliativo seja plural e com inúmeros conceitos distintos, esse artigo apresenta uma síntese permitindo aos tomadores de decisão apreciarem melhor os processos inovadores de suas organizações, assim como estimar de forma mais adequada os riscos de sucesso ou fracassos de suas intervenções a partir da melhor compreensão de determinantes críticos na fase de implantação.

Palavras-chave: Avaliação em saúde, Inovação organizacional, Intervenções de saúde, Implementação.

\section{RESUMEN}

Objetivo: Este artículo tiene por objetivo identificar y proporcionar al lector las bases para evaluar las innovaciones propuestas en organizaciones de salud y resaltar los determinantes a considerar en el momento de implementarlas. Revisión bibliográfica: No existe una definición de evaluación en salud que sea completa, exhaustiva y absoluta. Han sido identificados diversos enfoques y herramientas de evaluación que pueden ser adaptados y utilizados en función de los objetivos evaluativos, paradigmas e influencias teóricas del evaluador. Además, fueron evidenciadas y sintetizadas consideraciones relevantes sobre la implementación de las innovaciones, permitiendo al lector entender mejor la complejidad de esta fase y su impacto en el éxito de las innovaciones propuestas. Consideraciones finales: Si bien el campo de la evaluación es plural y con numerosos conceptos diferentes, este artículo presenta una síntesis que permite a los tomadores de decisiones evaluar mejor el proceso de innovación de sus organizaciones, así como estimar el riesgo de éxito o fracaso de sus intervenciones a partir de una mejor comprensión de los determinantes críticos de la fase de implementación.

Palabras claves: Evaluación en salud, Innovación organizacional, Intervenciones en salud, Implementación.

\footnotetext{
1 École de santé publique, Université de Montréal, Québec - Canadá.

*E-mail: breitner.gomes.chaves@umontreal.ca

2 Université du Québec à Trois-Rivières, Québec - Canadá.
} 


\section{INTRODUCTION}

Healthcare systems are becoming more and more complex, flexible, and adaptive than ever. They are finding it difficult to propose solutions at the same speed as the emerging needs of the population. New technologies have allowed users to interact with health services and obtain information at a speed never seen in human history. This has promoted restructuring in large companies' management style and governance in the healthcare sector. They seek to incorporate more flexible, dynamic, and interactive elements into their business model to align their strategies with current healthcare challenges and trends (LARISCH LM, et al., 2016).

However, researchers agree that the expansion of new technologies has contributed to a general increase in the cost of healthcare systems worldwide. Besides, they have reported tensions in the relationship among technologies, users, companies, consumers, the state, and health professionals. Another important dilemma has been the unprecise definition of "health technologies", making it challenging to assess their effectiveness or impacts. Indeed, there is an extensive conceptual variation on innovation in the health sector, and such perspectives may vary among the private, public, and third sectors (RICCIARDI W, et al., 2019).

Given the need to optimize the rising costs of healthcare organizations in the face of the emerging needs of an aging population, evaluation strategies for new technologies are imperative. Many studies have pointed out that new technologies should be evaluated as early as possible and re-evaluated frequently. Both the health outcomes and the economic impact of technological increment should be part of these evaluations (RICCIARDI W, et al., 2019).

When correctly performed, evaluation processes can support the financial balance of organizations and health systems, favoring a higher quality of services. In this context, evaluation is one of the best ways to meet the needs of decision-makers in terms of information. Also, evaluation can be considered an essential resource in the decision-making process since decision-makers have the responsibility to justify their choices to taxpayers and stakeholders (BROUSSELLE A, et al., 2011).

Given the relevance of the issue, evaluating innovations has been the subject of numerous studies to create new research models suitable for emerging research questions. Likewise, the field of implementation science is advancing every day to provide scientific evidence for organizations to maximize the implementation of their creative process (DAMSCHORODER LJ, et al, 2009; GREENHALGH T, et al., 2009; MIGLIORINI L, et al., 2019).

Therefore, this article identifies and presents some of the main evaluation approaches for innovations in the health field. Besides, this review highlights essential considerations while implementing innovations in healthcare organizations.

\section{BIBLIOGRAPHIC REVIEW}

\section{Innovation assessment}

Often health interventions (or innovations) are complex. Complex interventions have specific key characteristics: 1) they are defined and adapted according to the context; 2) each actor has a particular conception of the intervention, but they remain interdependent with a certain degree of decision-making autonomy; 3 ) the stability of these interventions results from the balance between, on the one hand, the adoption of collective norms and values in the structures and, on the other hand, their appropriation by the actors; 4) the structures influence the practices of the actors and the intervention processes (CONTANDRIOPOULOS AP, et al., 2011; BILODEAU and POTVIN L, 2018).

There is no one definition of evaluation that is complete, exhaustive, and absolute. The evaluation concept can vary depending on the research design, the methods and tools used, and the influence of certain contextual aspects. Nevertheless, some concepts have similarities (PYRCZAK F and TCHERNI-BUZZEO M, 2018). 
For example, evaluation is to make a "value judgment" on innovation by implementing a method or set of techniques likely to provide data on this intervention or its components to orient the various actors involved in making decisions to improve or interrupt an innovative process (BROUSSELLE A, et al., 2011; DONALDSON SI, 2007; MCGILL E, 2020).

However, evaluation is not only about the application of rigorous academic methodologies. In complex environments, it is often necessary to move beyond the linear logic of the assessment, adapt negotiation and engagement strategies with stakeholders, make feedback rounds, and allow openness to error and adjustments (DONALDSON SI, 2007).

Besides, evaluation has at least three purposes. First, a strategic aspect when it helps in the planning and development of an innovation. Second, a formative perspective provides information to improve an intervention along the way and, finally, a summative aspect when it aims to produce information on the effects of the intervention to decide whether to maintain or interrupt it. In general, there are two types of evaluation: normative evaluation and evaluative research (BROUSSELLE A, et al., 2011; DENFORD S, et al., 2017).

The normative evaluation examines the components of an intervention compared to a norm or standards. In other words, the normative evaluation seeks to know whether some criteria have been met (BROUSSELLE A, et al., 2011). Examples of normative evaluation are hospital accreditation processes, assessment by national health agencies, and best practice guidelines (CHAVES BG, et al., 2021a).

On the other hand, evaluative research examines how and why the results were achieved (JACOBSEN $\mathrm{KH}, 2020$ ). Evaluative research seeks to establish a causal link between the different components of an intervention. Also, evaluative research analyzes the relevance of each intervention core component and the differences between them. When implementing an innovation, managers want to understand better the repercussions of these interventions on their organization's environment. Therefore, depending on the expected objectives, the approach and angle of analysis may vary. For instance, Chart 1 summarizes the main types of evaluative research (BROUSSELLE A, et al., 2011).

Chart 1 - Types of evaluative research of an innovation.

\begin{tabular}{|c|c|c|}
\hline $\begin{array}{l}\text { TYPE OF } \\
\text { EVALUATION } \\
\text { RESEARCH }\end{array}$ & OBJECTIVES & COMMON METHODOLOGIES \\
\hline Logical analysis & $\begin{array}{l}\text { Assess the adequacy of the intervention's } \\
\text { theory and potential outcomes. }\end{array}$ & $\begin{array}{l}\text { Systematic and non-systematic } \\
\text { reviews; realistic synthesis; } \\
\text { consultation with experts. }\end{array}$ \\
\hline Effects analyses & $\begin{array}{l}\text { Assess the efficacy of the proposed } \\
\text { innovation, ensuring that the effects observed } \\
\text { are due to the proposed innovation }\end{array}$ & $\begin{array}{l}\text { Experimental or } \\
\text { experimental strategies }\end{array}$ \\
\hline Production analysis & $\begin{array}{l}\text { The analysis of production studies the } \\
\text { relationships between the resources used } \\
\text { (means) and the volume and quality of } \\
\text { services produced (activities) }\end{array}$ & $\begin{array}{l}\text { Methods derived from the } \\
\text { economic field, such as cost } \\
\text { accounting. }\end{array}$ \\
\hline Efficiency analysis & $\begin{array}{l}\text { It aims to study the relationships between the } \\
\text { resources and the effects observed }\end{array}$ & $\begin{array}{l}\text { Economic analyses (cost-benefit } \\
\text { analysis, } \quad \text { cost-effectiveness } \\
\text { analysis, etc.) }\end{array}$ \\
\hline $\begin{array}{l}\text { Implementation } \\
\text { Analysis }\end{array}$ & $\begin{array}{l}\text { It focuses on the relationships between the } \\
\text { intervention, its components, and the context }\end{array}$ & $\begin{array}{l}\text { Case studies } \\
\text { Mixed methods }\end{array}$ \\
\hline
\end{tabular}

Source: Chaves BG, et al., 2021; data extracted from Brousselle A, et al., 2011.

Another approach that seeks to reconcile the academic community with the dynamic needs of decisionmakers is the notion of Health Technology Assessment (HTA). HTA is a field of science policy research that adopts various approaches to evaluate technologies and support decision-making. This multidisciplinary field intends to incorporate in its approaches scientific evidence to predict the clinical, economic, cultural, ethical, and political impacts of the technologies, taking into account the particularities of the local context, the available resources, and the alternatives to the proposed solutions (CHEN Y, et al., 2018). 
Some countries have adopted a technology assessment policy at the governmental level (e.g., UK and Canada). However, the incorporation of technologies is often decided by health organizations (and their members, usual physicians) in most countries. Such countries are not (or partially) guided by national policies. Some authors, however, have criticized HTA. They consider it to be excessively mechanistic. One way to address this would be incorporating stakeholder values, more flexible processes, and the construction of deliberative spaces (GARCÍA-LEÓN FJ, 2019).

Also, several authors have emphasized the importance of analyzing the pertinence of the innovations before deciding to implement them (DENFORD S, et al, 2017). To do it, Chaves BG, et al. (2021a) propose ten key questions: the initial ten points for judging the pertinence of innovations in healthcare organizations (Chart 2).

Chart 2 - Ten key questions for assessing the pertinence of innovations in health organizations.

\section{Reflection questions for evaluating the pertinence of innovations in healthcare organizations}

1-Does this innovation solve one or several problems in our organization?

2-Does this innovation meet the real needs of our patients or employees? Does it solve the identified problems?

3-Does this innovation add value to our patients or services?

4-Is it ethical and responsible (respects the environment and local culture)?

5 -Does this innovation increase or reduce any form of social or health inequity?

6-Can we manage existing conflicts of interest by implementing this innovation?

7- Are the different stakeholders (immediate managers, healthcare professionals, users) involved and participate in the project from its initial phase?

8-Is this innovation compatible with our organization's values and mission (and health professionals and their respective professional associations)?

9-Are the implementation and operational costs reasonable and assumable by our financial reality?

$10-$ Is it possible to measure its effects and impacts?

Source: Chaves BG, et al, 2021, data extracted from Chaves BG, et al., 2021a.

\section{Standard tools and approaches used in the real world.}

In general, evaluating complex and innovative interventions applies some tools, models, or approaches (MILLS TR, et al, 2019). Several tools have been proposed to facilitate the evaluative process according to the epistemological perspectives and paradigms of the researchers and the research objectives (MILLS TR, et al, 2019). Some of the main types are described as follows (not exhaustive).

First, the logic model. Logical models have been used for decades for multiple purposes, and there is a vast literature on this concept. Broadly, the logical model is a strategy to simplify visually the relationships between the mobilization of resources needed for activities that are supposed to promote a complex "path of change" that will ultimately result in the desired effects of the intervention (HUDON C, et al., 2020; MILLS TR, et al., 2019).

Therefore, logic models are an easy way to represent a program theory (CHAVES BG, et al, 2021b). In general, they use the design type "input-activities-outputs-outcomes," and the level of complexity introduced into the specification of each component can vary with the evaluator's skills and research complexity ad goals (NARUSE T, et al., 2020).

Some authors have criticized the linear character of the logic model (MILLS TR, et al, 2019). Due to the complexity of health interventions, such static models often do not predict the interactive dynamics of the intervention with its environment. Hence, there is a tendency to integrate techniques capable of identifying contextual elements interacting with intervention, acting as "moderators" variables in producing the expected results by the proposed innovations (SUBIRANA M, et al., 2013).

Second, the context, input, process, product (CIPP) model. The CIPP Model evaluations focus on innovation improvement instead of proving something about the innovation (STUFFLEBEAM DL and CORYN 
CL, 2014). The approach emphasizes innovation context, inputs, processes, and products. The CIPP model addresses all phases of innovation. Therefore, from planning and implementation phases to a summative or final assessment.

The model fits for both formative studies (those interested in analyzing context, inputs, and process) and summative studies (those interested in analyzing the products of an intervention) (STUFFLEBEAM DL and ZHANG G, 2017). Also, this approach adds a critical element compared to the traditional logical model, the context. Many authors describe contextual elements as fundamental to understanding both the production of outcomes and the degree of implementation from interventions, such as external policies, social or organizational values, organizational climate, and leadership (LUI JHL, et al., 2021; MOULLIN JC, et al., 2019).

Third, the analysis of implementation. This approach examines the link between an innovation/intervention, its components, and the context influencing both implementation and outcomes (VEILLETTE-BOURBEAU L, et al., 2017). In other words, the analysis of implementation seeks to determine the gaps created between the expected outcomes and those produced during the implementation of an innovation. Since the analysis of effects (or impacts) is sometimes limited by a dichotomous model like the "black box" (perspective "work" or "does not work"), the analysis of implementation integrates the context in its approach as an inseparable element of the real world of healthcare organizations (VEILLETTE-BOURBEAU L, et al., 2017).

Besides, the analysis of implementation is particularly relevant when an intervention is sensitive to contextual variations or a new intervention for which we do not understand the overall process or production of outcomes (CHAMPAGNE F, et al., 2011).

In summary, this approach serves four purposes: 1) To improve the quality of a program;2) To improve the evaluation of the effects; 3) To allow proper documentation of how resources were applied; 4) To improve future innovation implementation in other sites (CHAMPAGNE F, et al., 2011).

Regarding its classification, there are 3 types of analysis of implementation Type 1 (1a and $1 \mathrm{~b}$ ) focuses on studying the intervention's evolution or "transformation" and the degree of implementation. While type 1a aims to explain the adaptation of the intervention to the context, type $1 \mathrm{~b}$ seeks to explain the level of the integrality of the intervention. Type 2 aims to study the influence of variations in the implementation of the intervention on the effects. Finally, type 3 analyses the influence of the interaction of the implementation context and the intervention towards the observed outcomes or impacts (CHAMPAGNE F, et al., 2011).

Forth, the realist (realistic) evaluation approach is also a form of theory-driven evaluation as the analysis of implementation. This approach intends to study: "What works, for whom, in what respects, to what extent, in what contexts, and how?". To do so, evaluators in the realist evaluation approach identify first the underlying mechanisms that explain 'how' the outcomes are generated, usually described as in terms of contextmechanism-outcome (CMO) configuration (QUINTANS JR, et al., 2020).

Then, evaluators tend to create "verifiable theories" that would enable to reproduce (or transfer) the chances of success in implementing innovations, understanding in depth their relationship with the context and the mechanisms of action that produce the intervention outcomes. Besides, this approach assumes that there are no outcomes in the real world of organizations dissociated from a context and mechanisms of action. Thus, the transferability of innovation would only be evaluated if considering these three integrated elements (QUINTANS JR, et al., 2020).

\section{Considerations about innovations implementation}

The innovation implementation's success is multifactorial (OLIVEIRA LS, et al., 2018). In general, it depends on "the degree of change" and the transformation "accepted" by the environment. In other words, it results from a complex interaction of the innovation proposed, its acceptability by the environment, and elements of the organization and its external context (CHAVES BG, et al., 2021a). There are hundreds of different models (frameworks) that can serve as references for health workers and managers before and throughout the implementation of their innovation (his includes both in implementation science research analyses and in real-world implementation interventions) (MOULLIN JC, et al., 2020). 
Moullin JC, et al. (2020) highlight ten considerations for employing implementation frameworks in the implementation process:(1) select appropriate framework(s), (2) establish and maintain partnerships with stakeholders, (3) characterize the problem and detailed research questions and hypotheses, (4) develop a design for implementation or logic model; (5) To choose research and evaluation procedures, (6) identify implementation determinants, (7) adapt one or more implementation strategies, (8) define implementation outcomes, (9) use one or more micro-level frameworks to drive and adjust implementation, and (10) build the proposal and report.

Some of these frameworks have become popular and are widely used both in implementation science research and supporting implementation processes. For instance, Greenhalgh T, et al. (2004) undertook a study grouping evidence on the determinants that may influence the dissemination and implementation of innovations in healthcare organizations. Also, Rogers' diffusion model suggests understanding how "change" can be achieved in health organizations. This model suggests that some characteristics of the innovation may facilitate its adoption. For example, the complexity of the proposed change, the coherence with organizational values, the perception of the need by the parties involved, and the flexibility (or adaptability) of the proposed "solution." (SANSON-FISHER RW, 2004; ROGERS EM, 2010; MOHAMMADI MM, et al., 2018).

Rogers EM (2010) also described that the process of innovation diffusion has an "S" shaped dispersion pattern. In other words, every innovation would have 3 phases: 1) a slow initial phase that affects some members who are considered more "open"; 2) a fast-intermediate phase with considerable dispersion and adhesion; 3 ) the last phase of slow adhesion. Managers and health professionals should consider this because it is necessary to adopt a plan for each phase since the actors' characteristics, interests, and motivations are different in each phase and may rapidly change over time. Concerning the motivation and challenge of each phase, some authors suggest applying self-efficacy theory as a theory with the potential to support the managers to face the challenges of each step to enable the adhesion of the actors involved (MIGLIORINI L, et al., 2019).

Besides, Damschroder LJ, et al. (2009) described the "Consolidated Framework for Implementation Research" (CFIR) that offers an overarching typology to promote innovation implementation and research about what "works," "where," and "why" under multiple contexts. The CFIR was applied across various study objectives and settings, though more in-depth use of the CFIR was advanced implementation science.

The Promoting Action on Research Implementation in Health Services (PARIHS) has been refined and tested over 20 years. Context remains a central concept within PARIHS but with a broader focus. The context acts as "layers of influence" (from micro to macro levels). These "layers" can work to favor or constrain implementation. Therefore, context is described in terms of resources, culture, leadership, and orientation towards evaluation and learning (BIRKEN SA, et al., 2017).

Authors also have stressed that complex adaptive systems characterize by boundaries that are difficult to delimit. Indeed, actors operate according to internal rules that are not always predicted. These systems, such as health care organizations, interact, adapt, and co-evolve with other systems at multiple levels (BRAINARD $\mathrm{J}$ and HUNTER PR, 2016).

In this sense, the non-adoption, abandonment, scale-up, spread, sustainability framework (NASSS) studies the non-adoption challenges to disseminating and sustainability of technologies. This framework can be used when planning an intervention/innovation since it provides myriad determinates to reflect while implementing innovation in complex environments (GREENHALGH T and ABIMBOLA S, 2019). Also, the NASSS allows explaining success, failure, and unexpected events during innovations implementation when applied retrospectively, generating robust and contextualized information (ABIMBOLA S, 2019).

It is also worth mentioning that healthcare workers are not agents who passively receive innovations. In reality, they develop opinions and feelings (positives or negatives) about what is being proposed. In addition, they can be very interested and concerned about the innovation impacts. They can positively receive and adopt them, and sometimes they want to adjust, modify them to fit specific tasks or redesign them, and sometimes they can also reject them (GREENHALGH T and PAPOUTSI C, 2019). 
Besides, "change" is a complex phenomenon that can involve a range of "change agents". These agents may have varying roles and implications over time. Moreover, it is essential to note that innovation can cause imbalances in established routines, influencing the evaluation of ongoing innovations. Finally, it is imperative to consider power issues as a key determinant during the evaluation of innovation implementation (CHAVES BG, et al., 2021a).

\section{Responsible Research and Innovation (RRI)}

Another aspect of innovations increasingly gaining interest is the concept of Responsible Research and Innovation (RRI). The debate about responsible innovation has occupied a space of high relevance in the public and academic debates, mainly due to the technological revolution of health systems and their societal, human, and financial impacts (LEHOUX P, et al., 2021).

In this regard, there is a multitude of administrative and academic definitions of RRI. Roco MC, et al. (2011) have listed four characteristics of responsible innovation (1) transformative across sectors and disciplines, (2) taking into account equitable access, health, safety, and environmental concerns, (3) involvement across governmental institutions and other stakeholders, and (4) long-term measures to anticipate and adapt.

According to Silva HP, et al. (2018), RIH is a collaborative effort in which stakeholders are committed to a set of ethical, economic, social, and environmental principles from conception to distribution. These authors have suggested a model organized into five domains, including elements of population health, health system, economy and environment (SILVA HP, et al., 2018).

Although it is a framework designed to guide policy, these principles and criteria can easily be adapted to health care organizations, especially in countries or health systems where decision-making (incorporation of technologies) is usually still fragmented. Indeed, the challenges of creating a culture of responsible innovation in healthcare organizations have been the object of studies (LEHOUX P, et al., 2021).

\section{FINAL CONSIDERATIONS}

Looking for solutions to solve problems is part of human nature, and developing innovations may be the best way to do so. Innovation should bring solutions and not add new issues to existing ones. Evaluation can be a very supportive tool in predicting the success of the development and implementation of the innovation. However, evaluation should be considered as a human, political, and social process. This article presented considerations about evaluating innovations in the context of health organizations and considerations from the scientific literature regarding the challenges of implementing these innovations, especially given that healthcare organizations are complex environments. The process of evaluating an innovation, choosing strategies best suited to the research objectives and stakeholder interests can be considered both an art and a scientific ability.

\section{REFERENCES}

1. ABIMBOLA S, et al. The NASSS framework for ex post theorisation of technology-supported change in healthcare: worked example of the TORPEDO programme. BMC Medicine, 2019; 17(1): 233.

2. BILODEAU, A, POTVIN L. Unpacking complexity in public health interventions with the Actor-Network Theory. Health Promotion International, 2018; 33(1): 173-181.

3. BIRKEN SA, et al. Criteria for selecting implementation science theories and frameworks: results from an international survey. Implementation Science, 2017; 12(1): 124.

4. BRAINARD J, HUNTER PR. Do complexity-informed health interventions work? A scoping review. Implementation Science, 2016; 11(1): 127.

5. BROUSSELLE A, et al. L'évaluation: concepts et méthodes. 2nd ed. Les presses de l'Université de Montréal, 2011.

6. CHAMPAGNE F, et al. A análise de implantação. Avaliação: conceitos e métodos. Rio de Janeiro: Editora Fiocruz:6174, 2011.

7. CHAVES BG, et al. Innovation in Healthcare Organizations: Concepts and Challenges to Consider. International Journal of Health Research and Innovation , 2021a; 9(1). 
8. CHAVES BG, et al. Logic model for mental health interventions: the recovery college model in Quebec, Canada. Development Research, 2021b; 11(07): 48781-48784.

9. CHEN Y, et al. Development of health technology assessment in China: New challenges. Biosci Trends, 2018; 12(2): 102-108.

10. CONTANDRIOPOULOS A, et al. Évaluer une intervention complexe: enjeux conceptuels, méthodologiques, et opérationnels. The Canadian journal of program evaluation, $2011 ; 26(3): 1$.

11. DAMSCHRODER LJ, et al. Fostering implementation of health services research findings into practice: a consolidated framework for advancing implementation science. Implementation Science, 2009; 4(1): 50.

12. DENFORD $\mathrm{S}$, et al. Fostering implementation of health services research findings into practice: a consolidated framework for advancing implementation science. Implementation Science, 2017; 4(1): 50.

13. DONALDSON S. Program theory-driven evaluation science: Strategies and applications. Routledge, 2007.

14. GARCÍA-LEÓN FJ. Ethics in health technology assessment. Review Journal of healthcare quality research, 2019 ; 34(1): 20-28.

15. GREENHALGH T, ABIMBOLA S. The NASSS Framework - A Synthesis of Multiple Theories of Technology Implementation. Stud Health Technol Inform, 2019; 263: 193-204.

16. GREENHALGH T, PAPOUTSI C. Spreading and scaling up innovation and improvement. BMJ, 2019; $365: 12068$.

17. GREENHALGH T, et al. Diffusion of innovations in health service organisations: a systematic literature review. 2008.

18. HUDON C, et al. Evaluating complex interventions in real context: Logic analysis of a case management program for frequent users of healthcare services. Evaluation and program planning, 2020; 79: 101753.

19. JACOBSEN KH. Introduction to health research methods: A practical guide. Jones \& Bartlett Publishers, 2020.

20. LARISCH LM, et al. Understanding healthcare innovation systems: the Stockholm region case. Journal of health organization and management, 2016.

21. LEHOUX P, et al. Moving Towards Responsible Value Creation: Business Model Challenges Faced by Organizations Producing Responsible Health Innovations. Journal of Product Innovation Management, 2021.

22. LUI JH, et al. Outer-context determinants in the sustainment phase of a reimbursement-driven implementation of evidence-based practices in children's mental health services." Implementation Science, 2021; 16(1): 82.

23. MCGILL E, et al. Qualitative process evaluation from a complex systems perspective: A systematic review and framework for public health evaluators. PLoS medicine, 2020; 17(11).

24. MIGLIORINI L, et al. How Could Self-Determination Theory Be Useful for Facing Health Innovation Challenges? Frontiers in Psychology, 2019; 10(1870).

25. MILLS T, et al. Advancing complexity science in healthcare research: the logic of logic models." BMC medical research methodology, 2019; 19(1): 55-55.

26. MOHAMMADI MM, et al. Evaluating the adoption of evidence-based practice using Rogers's diffusion of innovation theory: a model testing study. Health Promot Perspect, 2018; 8(1): 25-32.

27. MOULLIN JC, et al. Ten recommendations for using implementation frameworks in research and practice." Implement Sci Commun, 2018; 1: 42.

28. MOULLIN JC, et al. Systematic review of the Exploration, Preparation, Implementation, Sustainment (EPIS) framework. Implementation Science,2019; 14(1): 1.

29. NARUSE, T, et al. A Logic Model for Evaluation and Planning in an Adult Day Care for Disabled Japanese Old People. Int J Environ Res Public Health, 2020; 17(6).

30. OLIVEIRA LS, et al. Critical success factors for open innovation implementation. Journal of Organizational Change Management, 2018.

31. PYRCZAK F, TCHERNI-BUZZEO M. Evaluating research in academic journals: A practical guide to realistic evaluation. Routledge, 2018.

32. QUINTANS J, et al. Realist evaluation for programs and services in the health area: an integrative review of the theoretical and methodological literature. Rev Lat Am Enfermagem, 2020; 28: e3255.

33. RICCIARDI W, et al. How to govern the digital transformation of health services. Eur J Public Health, 2019; 29(3): 712.

34. ROGERS EM. Diffusion of innovations. Simon and Schuste, 2010.

35. SANSON-FISHER RW. Diffusion of innovation theory for clinical change. Medical journal of Australia, 2004; 180: S55S56.

36. SILVA HP, et al. Introducing responsible innovation in health: a policy-oriented framework. Health research policy and systems, 2018; 16(1): 90.

37. STUFFLEBEAM DL, CORYN CL. Evaluation theory, models, and applications. John Wiley \& Sons, 2014.

38. STUFFLEBEAM DL, ZHANG G. The CIPP evaluation model: How to evaluate for improvement and accountability: Guilford Publications, 2017.

39. SUBIRANA M, et al. A realist logic model of the links between nurse staffing and the outcomes of nursing. Journal of Research in Nursing, 2013; 19(1): 8-23.

40. VEILLETTE-BOURBEAU L, et al. Analyse d'implantation d'une recherche intervention sur le dépistage rapide du VIH dans la communauté gaie montréalaise. Canadian Journal of Program Evaluation, 2017; 32(1). 